\title{
Spindle Cell Nevus
}

National Cancer Institute

\section{Source}

National Cancer Institute. Spindle Cell Nevus. NCI Thesaurus. Code C66758.

A nevus characterized by the presence of spindle-shaped melanocytes. 